\title{
Retailing strategy The need for revision of the traditional orientation
}

\author{
M. Leibold \\ Department of Business Economics, University of Stellenbosch
}

The central theme of this article is that the traditional orientation to retailing strategy seems inadequate to cope with changing environmental realities of especially the past decade. The traditional concept of retailing strategy is analysed, and the general marketing strategy nature thereof is indicated. The difference between enterprise and marketing strategy is highlighted, and the nature and importance of a broadened enterprise strategy emphasis are stressed. The latter approach incorporates three hierarchial levels of strategy orientation, which lead to appropriate decisions regarding the character, scope and mission of a retail enterprise's activities.

S. Afr. J. Bus. Mgmt. 1983, 14: $161-165$

Die sentrale tema van hierdie artikel is dat die tradisionele oriëntasie tot kleinhandelstrategie ontoereikend is om die veranderende omgewingsrealiteite van veral die afgelope dekade te hanteer. Die tradisionele konsep van kleinhandelstrategie word ontleed, en die algemene bemarkingstrategie-aard daarvan aangedui. Die verskil tussen ondernemings- en bemarkingstrategie word toegelig, en die aard en belangrikheid van ' $n$ breëre ondernemingstrategiebeklemtoning word onderstreep. Die laasgenoemde benadering omvat drie hiërargiese vlakke van strategie-orièntasie, wat lei tot toepaslike besluite aangaande die karakter, omvang en missie van 'n kleinhandelsonderneming se aktiwiteite.

S.-Afr. Tydskr. Bedryfsl. 1983, 14: 161- 165

\section{Introduction}

In the Republic of South Africa, as in most developed Western countries, the structure and nature of retail institutions and activities during the past decade have been in rapid transition as a result of significant environmental changes. ${ }^{1}$ The retail management dreams and views of the 1960s and early 1970s of automatic growth opportunities for retail enterprises based upon a continually growing economy, expanding consumer demand and ever-increasing living standards have largely vanished. Instead, retail enterprises are faced with increasing pressures and problems, some of which are:

- rapidly changing consumer expectations, attitudes, lifestyles and buying patterns;

- intensification of retail trade competition (with a bewildering array of new retail institutions and merchandising innovations);

- increasing conflict and concentration of power in marketing channels;

- high enterprise cost structures due inter alia to limited and increasingly expensive resources;

- and growing pressures from the private and public sectors of the economy (e.g., consumerism and legislation).

In retail management the acceptance of change as a normal way of life, and the assignment of high priorities to developing creative adaptations to change, have become essential. These creative adaptations are concerned with a continuous optimizing of the retail enterprise's relationships with its environment, and result from rational planning of the future direction of the firm, also known as its enterprise strategy.

Many retailers, wholesalers and even manufacturers who could not anticipate or adapt to new developments in the environment have been forced out of business or taken over and rejuvenated by others. A recent example is that of Greatermans stores. ${ }^{2}$ Usually, when economic conditions are favourable and consumer demand is expanding rapidly, the momentum tends to let even the inefficient and complacent retail enterprises survive. In recessionary, stagnant, or slowexpanding economic conditions, the complacent and strategically less aware retail enterprises quickly disappear from the scene.

These facts pose a specific and demanding challenge to retailing firms concerning their orientation towards the concept of enterprise strategy. Research conducted by the author has revealed that the traditional conceptual orientation of retailing strategy is seriously deficient to cope with changing environmental realities, in that it emphasizes a marketing strategy instead of an enterprise strategy approach. ${ }^{3}$ 


\section{The traditional concept of retalling strategy}

Strategy is the term given to a special type of plan; it evolved originally in the military context, where it was used (and still is) to indicate overall plans of action made in view of the environment (terrain, weather, etc.), own capabilities of the planner, and current and anticipated competitive behaviour. ${ }^{4}$ The concept of tactics is closely related to strategy, and refers to the operational means or methods used in implementing the strategic plan.

Retailing strategy can thus be seen as a comprehensive plan of action designed in view of known or anticipated environmental conditions (including competition), for the purpose of bringing the retail enterprise into accommodation with its market environment and achieving its objectives. In the context of systems reasoning, this means an organized movement and counter-movement to bring a harmonious balance between the input and output of the retail management system. It is therefore a means whereby the retail enterprise reacts (either adaptively or innovatively) to the conditions of the market place in order to ensure its survival.

The development of a retailing strategy is usually seen as a two-part process: Firstly, it consists of the selection of a target market via the process of market segmentation; and secondly, the development of a unique retailing mix composition. ${ }^{5}$

\section{Selection of a target market}

In retailing several market opportunities exist for any particular enterprise. No single retail enterprise can, however, hope to be all things to all potential customers, because of the wide diversity of consumer needs in the market place and concomitant retailing activities. The problem then is to find the best market opportunity for which to strive in the light of the enterprise's objectives, resources and abilities, and environmental constraints (especially competition), in order to attain differential advantage in the market place. The target market is selected through a process of market segmentation, which is the grouping or clustering of consumers according to relatively homogeneous sets of demand characteristics. Examples of such clusters are the young homemaker market, the do-it-yourself market, the baby market, the jet-set market and the teenagemarket.

Market segmentation is in itself a highly volatile notion which is continually subject to change. There is no single, simple stratification of the population today as there seemed to be in earlier decades. ${ }^{6}$ The important point, however, is that retail enterprises attempt to scale down the total market opportunity to something smaller, which is a target market, and today often strive to develop an 'image' or cognition pattern that matches the cognition pattern of a given cluster of consumers. This is essentially part of the activities involved in building a strategy for the retail firm in order to achieve differential advantages. Viewed within a retail systems framework, the overall consumer market is part of the uncontrollable environment influencing the retail management system. This necessitates continuous monitoring, analysis, evaluation and prediction in terms of the nature of consumer market opportunities, its location, its sizes, and its special attributes.

\section{The retailing mix}

Once the target market has been decided upon retail management need to plan and develop a composite retailing mix, which is a bundle of unique and special offerings which the enterprise presents to its target market. The strategic elements com- posing the retailing mix are the enterprise's prices, its product or inventory assortments, its promotional activities and its place or locational considerations. Optimal satisfaction of the consumers forming the target market depends on the correct emphasis given to each of the mix components, as well as through optimal blending of the components to form a coherent whole. It is a total programmed effort by retail management to adjust the outputs of their system in accordance with the demands perceived in their target market.

Lazer and Kelley ${ }^{7}$ view the retailing mix as consisting of three sub-mixes, as illustrated in Figure 1.

The three sub-mixes are the goods and service mix, communications mix, and physical distribution mix, with each including a wide range of activities under its classification. Some authors prefer an expanded classification of the elements of the retailing mix, but essentially all of these traditional classifications boil down to the four principal items of place, product, price and promotion. ${ }^{8}$ In the same way as the retail enterprise can attain differential advantage through market segmentation and unique target market selection, it is also possible through a unique retailing mix composition, or both.

The above-mentioned orientation to retailing strategy corresponds with the marketing strategy paradigm first proposed by McCarthy, ${ }^{9}$ and since generally accepted as a framework for marketing strategy decision-making. The reason for this seems to lie in the fact that the field of retail management is viewed predominantly from a macro-marketing standpoint, as the retail trade forms part of the marketing system of a country. Consequently, most retailing literature equate retailing strategy with marketing strategy, not fully appreciating that a retail firm is a business institution in its own right which should employ enterprise strategy thinking to guide its actions.

\section{The difference between enterprise and marketing strategy}

Explanation of the difference between enterprise and marketing strategy is a complex task because of the close interrelationships existing between them. In fact, the difference is far from categorical, but rather one of orientation, emphasis or degree.

Ansof ${ }^{10}$ states that enterprise strategy is one which '(a) provides a broad concept of the firm's business, (b) sets forth specific guidelines by which a firm can conduct its search for markets, and (c) supplements the firm's objectives with decision rules which narrow the firm's selection process to the most attractive opportunities'. ${ }^{11}$ Most writers agree on four basic components of enterprise strategy: market opportunity; corporate competence and resources; personal values and aspirations of top executives; and a sense of corporate purpose or mission. When evaluating these four components, Kotler con cludes that 'strategic planning is based upon the key concepts of market evolution and strategic fit. All markets undergo an evolutionary unfolding marked by changing customer needs, technologies, competitors, channels and laws'. ${ }^{12}$ Abell contends that the enterprise should be looking out of a 'strategic window' monitoring these changes and assessing the requirements for continued success in the market. ${ }^{13}$ Irrespective of whether strategy is seen as a concept, process, or plan, it is clear that enterprise strategy is concerned with the firm's overall character, philosophy and purpose.

Marketing strategy has been defined as a sequence of deci sion rules which give a description of the marketing practices of a company, their order and their timing. ${ }^{14}$ Marketing strategy development, as stated previously, is usually viewed as consisting of two distinct and yet interrelated parts, namely 


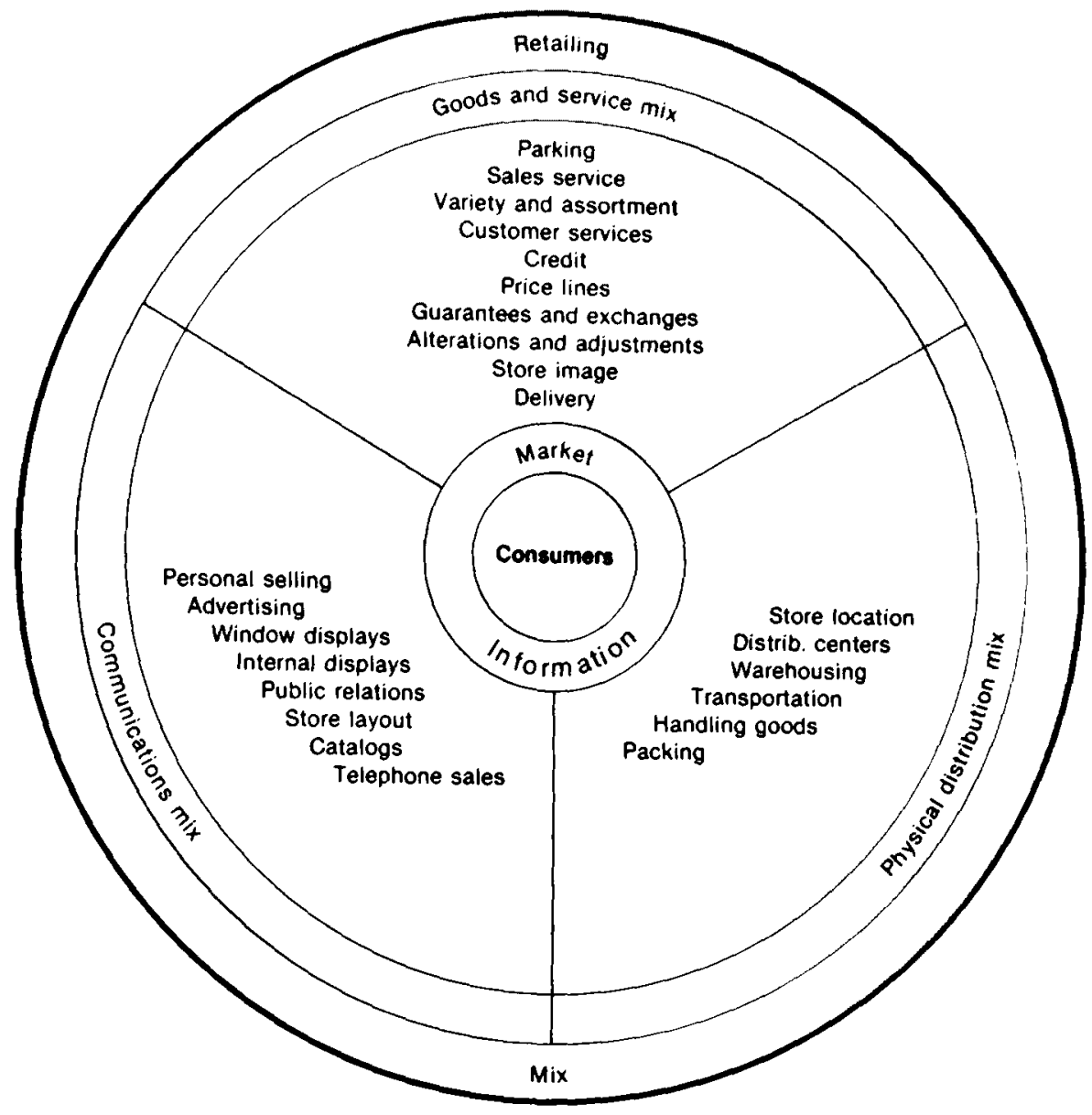

Figure 1 The retailing mix.

a target market and a marketing mix. While the enterprise strategy planning process is an activity involving managers representing all areas of the firm, marketing strategy planning is seen as a lower-level activity, involving mainly managers from the marketing department. On the other hand, it is clear that a good enterprise strategy should be market-orientated, and it may be that the marketing department's strategic plan may set the tone and direction for the whole company. However, when equating marketing strategy with enterprise strategy, the danger of a myopic or shortsighted view to the overall purpose and capabilities of the enterprise is likely to arise; for example, marketing functionaries are normally inclined to lend greater weight to marketing resources than to overall enterprise resources in setting marketing objectives. Because of their position in the enterprise's hierarchy, the marketing officials are often not capable to view the enterprise and its capabilities in total perspective. Katz appropriately states that 'Dealing with the total enterprise provides challenges and opportunities which do not exist in the management of a single part'. ${ }^{15}$

It is appropriate, therefore, to think of an enterprise needing two levels of strategic planning - first, for the entire firm and, second, for each department (including the marketing department). The top management level would focus on companywide objectives, the management's view of its mission, and what it could achieve with its capabilities taking into accont environmental opportunities and threats. The marketing management level would focus on marketing objectives and target markets consistent with the enterprise mission and purpose, appropriate policies and plans regarding the use of marketing resources to achieve objectives (mainly using the marketing mix variables), marketing organization design, and evaluation and control of marketing activities. It must be remembered, however, that development of enterprise strategy incorporates elements relating to marketing, such as marketing's knowledge of markets, competition, innovation and market standing.

\section{An enterprise strategy emphasis in retailing}

The concept of enterprise strategy has evolved only during the past two decades, especially in response to the conglomerate movement and continued diversification, takeovers and mergers among companies. However, even in undiversified firms the concept of enterprise strategy finds application, since it is being recognized that every firm consists of various parts or elements which together constitute its character or nature.

Three hierarchial levels of enterprise strategy decisionmaking can be discerned, namely corporate, business and functional.

\section{Corporate strategy}

Corporate strategy approaches centre around the analysis and determination of the types and nature of businesses that the enterprise should be in, i.e. if the enterprise should accommodate various business entities under its corporate 'umbrella' in view of environmental opportunities and constraints and the enterprise's objectives and resources. It is obvious that an enterprise can easily become a collection of diverse and confusing business interests, with little common purpose and overall thrust, if corporate strategy thinking is not conducted in a formalized, rational way. Four essential and interrelated components of such approaches can be stated, namely scope, resource deployments, competitive advantages, and synergy: ${ }^{16}$ 
- Scope involves the extent of the enterprise's current business, and the major task is to determine the relative attractiveness of each of the firm's businesses for present and future investment/divestment through an analysis of the firm's overall portfolio. Part of this task is to determine whether such investments/divestments will permit the firm to achieve its overall objectives, to identify the various gap-closing options open to the firm, and to identify and evaluate new areas in which the firm might invest if it cannot meet its objectives through investments in its existing businesses. This component is sometimes referred to as the enterprise's domain, and the major conceptual tools employed in this regard are portfolio matrix analyses. ${ }^{17}$ Thus, retail firms such as Pep Stores, Edgars and Foschini have to continually review their portfolio of business entities.

- Resource deployments involve the levels and patterns of the enterprise's past and present resource and skill deployments among the different business entities in its corporate group, in order to achieve its objectives and goals.

- Competitive advantages concern the unique position an enterprise develops $v i s-\grave{a}$-vis its competitors through its patterns of scope and/or resource deployment decisions.

- Synergy concerns the joint effects or advantages that are sought from the enterprise's scope and/or resource deployments.

In sum, all strategy approaches at the corporate level of the enterprise centre around scope and resource deployment decisions, with competitive advantages and synergy important concomitant considerations.

\section{Business strategy}

Business strategy approaches focus on defining the single business unit ('what business am I in?') and determining the mission (or role) of the business. ${ }^{18}$

- Defining the business includes decisions concerning

- product and market scope: the interrelated dimensions of which customers are to be served, which customer needs are to be satisfied, and how customer needs are to be satisfied. Scope defines the extent to which a business participates in one or more customer groups, one or more customer needs, and one or more product groupings;

- product and market segmentation and differentiation: in particular, whether and how the business recognizes differences among customers in terms of their needs and the ways they are satisfied. Segmentation and differentiation define how a business participates along each of the three scope dimensions, with possibilities of distinct competences to be discerned and insulation from imitation by competitors.

- Determining the mission (or role) of the business entails decisions regarding performance expectations in terms of sales growth, market share, return on investment, net income, and cash flow. This demands a careful analysis of market opportunities and company capabilities, as well as a regard for overall corporate objectives. In this sense the term mission means a set of objectives, and decisionmaking often involves making explicit trade-offs among potentially conflicting objectives, especially because objectives regarding growth, market share gain, profit and liquidity cannot all be achieved simultaneously.

Business definition is the first step in planning a strategic market approach for two major reasons. Firstly, business definition is a creative decision in its own right that can fundamentally affect the health of the business. Some definitions are strategically superior to others, either because they better satisfy customers' requirements, and/or because they fit the distinctive competence of the business particularly well, and/or because they insulate the business from competition. Secondly, a definition of the business and determining its mission logically precedes all other strategic decisions. An assessment of the relative viability (attractiveness) of a particular definition is an input to decision with respect to mission, i.e. to invest in, maintain, or withdraw from a business, because specific functional plans for actually sat isfying customer needs can only be formulated once business scope, segmentation and differentiation, and mission have been explicitly considered.

Unfortunately, it is relatively rare to find enterprises consciously and explicitly setting guidelines for its strategic market approaches. ${ }^{19}$ Businesses are still often defined by accident rather than design, with each product group or market extention looked at primarily on its own merits and not on the basis of its overall strategic impact. Thus, actions shape the definition rather than the definition shaping actions. To make matters worse, current business literature offers little beyond general exhortations that the business should be defined in one dimension or another. ${ }^{20}$ Theodore Levitt has suggested that firms should avoid 'marketing myopia'. ${ }^{21}$ This apparently implies that they should define themselves broadly in terms of the needs to be satisfied as opposed to a particular technology/product grouping (e.g., 'we are in the convenience needs satisfaction business and not in the supermarket business'). Hanan has suggested alternatively that customers should be the basis for business definition and that growth should occur by asking the question 'what other needs of the customers we know so well can we serve profitably?" ${ }^{22}$ None of these prescriptions tells management which factors should be considered in any particular situation, nor are any guidelines provided as to either scope or degree of segmentation and differentiation along dimensions other than the one highlighted by each author. Recently, however, a few authors have started to give attention to this problem. For example, Abell and Hammond suggest that in order to define the business and to determine an appropriate mission, market opportunities and company capabilities have to be assessed, and they provide guidelines in this regard; they, as well as Hofer and Schendel, also provide guidelines/aids for the determination of corporate as well as business strategy approaches. ${ }^{23}$

\section{Functional area strategy}

At the functional area level, the principal focus of strategy is on the maximization of resource productivity. Synergy and the development of distinctive competences become the key strategic components, while scope drops sharply in importance. At this level synergy involves the co-ordination and integration of activities within a single function.

\section{Conclusion}

The traditional concept of retailing strategy, with its predominant marketing strategy character, gives the retail enterprise a myopic view of its basic purpose or mission, or what this purpose or mission should be. Instead of the narrow emphasis on target market and retailing mix composition, the concept of retailing strategy should be broadened to include an appreciation of the enterprise's objectives, capabilities, competition, consumer market opportunities, and the distributive structure. 
While the basic tenets of the marketing strategy concept still holds in retailing strategy decision-making, these should be relegated to a lower order, and viewed as an essential buildingblock or stone in the final composition of the retail enterprises's overall strategy. In view of the increasing rate of change in the market environment, the retail enterprise should give more prominence to what business it really is in, what business it should be in, where it wants to go, and if it is capable to achieve it. Again, the difference in outlook cannot be stated categorically; rather, it is a difference in emphasis. For example, instead of accepting the fact that it is in the 'supermarket business' or 'furniture retailing' and delineating a target market and composing an optimal retailing mix, a retail firm would, using the broadened enterprise concept of retailing strategy, question the nature and future of the line of retail business it is in. After having carefully evaluated the current and foreseen market environmental changes, and taking account of its current and expected future capabilities, the realization could possibly be made that a new business character is necessary, e.g., 'convenience goods' retailer or 'living environment' retailer, which has to acquire a uniquely differentiated character in order to survive.

\section{References}

1. Leibold, M. Retailing strategy in the changing South African market environment, Unpublished D.Comm.-dissertation, Stellenbosch: University of Stellenbosch; 1981, chapters 3, 4 and 5 .

2. Friedland, R. What went wrong at Greatermans Stores? Management, July 1982, p.35.

3. Leibold, M., op. cit.

4. Rachman, D.J. Retail strategy and structure: A management approach. Englewood Cliffs, N.J.: Prentice-Hall, Inc., 1969, p.23.

5. James, D.L., Walker, B.J. \& Etzel, M.J. Retailing today: an introduction. New York: Harcount Brace Jovanovich, Inc., 1975, p.33.

6. Schinkel, T. Multiple Concepts: An Answer to the Struggle for New Growth, Stores, June 1976, p.34

7. Lazer, W. \& Kelley, E.J. The retailing mix: planning and management, Journal of Retailing, vol.37, Spring 1961, p.37.

8. Gist, R.R. Basic retailing: text and cases, Second Edition. New York: John Wiley and Sons, Inc., 1971, p.66.

9. McCarthy, E.J. Basic Marketing: A Managerial approach. Sixth Edition. Homewood, Illinois: Richard D. Irwin, 1978. p.39. (First Edition, 1960).

10. Ansoff, H.1. Corporate strategy. New York: McGraw-Hill, Inc., 1965, p. 96

11. Ibid.

12. Kotler, P. Marketing management: analysis, planning and control, Fourth Edition. Englewood Cliffs, N.J.: Prentice-Hall, Inc., 1980, p.64.

13. Abell, D.F. Strategic Windows, Journal of Marketing. July 1978, p.21.

14. Van der Merwe, S. \& Van der Merwe, A. South African marketing strategy: text and cases. Cape Town: Juta and Company, Limited, 1975, p.8.

15. Katz, R.L. Cases and concepts in corporate strategy. Englewood Cliffs, N.J.: Prentice-Hall, Inc., 1970, p.7.

16. Hofer, C.W. \& Schendel, D. Sirategy formulation: analytical concepts. St Paul, Minnesota: West Publishing Company, 1978, p.25

17. Abell, D.F. \& Hammond, J.S. Strategic market planning. Englewood Cliffs, N.J.: Prentice-Hall, Inc., 1979, p.12.

18. Thompson, A.A. Jr. \& Strickland, A.J. Strategy and policy: concepts and cases. Dallas, Texas: Business Publications, Inc., 1978, pp.9- 10 .

19. Abell, D.F. \& Hammond, J.S., op. cit., p.396.

20. Ibid., p.397.

21. Levitt, T. Marketing Myopia. Harv. Bus. Rev. July-August, 1960.

22. Hanan, M. Reorganize your company around its market. Harv. Bus. Rev. November - December 1974, p.63.

23. Hofer, C.W. \& Schendel, D., op. cit.; and Abell, D.F. \& Hammond, J.S., op. cit. 